\title{
The Malaysian Private Finance Initiative and Value for Money
}

\author{
Roshana Takim (Corresponding author) \\ Graduate Centre Department, Faculty of Architecture \\ Planning and Surveying, University Technology \\ MARA (UiTM) Shah Alam, Malaysia
}

Tel: 60-3-5521-1567 E-mail: rtakim59@yahoo.co.uk

Kharizam Ismail

Graduate Centre Department, Faculty of Architecture

Planning and Surveying, University

Technology MARA (UiTM) Shah Alam, Malaysia

Tel: 60-3-5521-1570 E-mail: khari511@yahoo.com.my

Abdul Hadi Nawawi

Graduate Centre Department, Faculty of Architecture

Planning and Surveying, University

Technology MARA (UiTM) Shah Alam, Malaysia

Tel: 60-3-5521-1568Ｅ-mail: hadinawawi@yahoo.com.my

\author{
Aini Jaafar \\ Deapartment of Quantity Surveying, Faculty of Architecture \\ Planning \& Surveying, University \\ Technology MARA (UiTM) Shah Alam, Malaysia \\ Tel: 60-3-5522-5341Ｅ-mail: aininjaafar@salam.uitm.edu.my
}

\begin{abstract}
The concept of value for money (VFM) is the fundamental reason for most PFI projects to be attractive in many developed and developing countries. The concept encourages governments to deliver Mega projects by using PFI procurement method. The aims of this paper are to investigate the notion of VFM for PFI projects by different countries (i.e. UK, Australia and Japan) and to discover the detailed components of Public Sector Comparator ( PSC ) protocol to evaluate VFM.

Based on the consideration of these models, the paper proposes a framework of VFM assessment for PFI projects in Malaysia. The proposed framework outlines six processes to be considered: key assessment criteria (affordability, risk sharing and competition) of VFM assessment; VFM assessment approach by using PSC; VFM appraisal by application of three tests (financial, qualitative and cost benefit analysis); VFM drivers; benefits; and barriers that could affect the VFM assessment process. Hence, achieving VFM can be described in terms of three core components; economic, efficiency and effectiveness of PFI projects. The framework developed in this paper will help to gain a better understanding of VFM in PFI projects and to establish PSC guideline in the evaluation of VFM.
\end{abstract}

Keywords: Private Finance Initiative, Public Sector Comparator (PSC), Risk allocation and Value for Money 


\section{Introduction}

Private Finance Initiative (PFI) was originated in England in 1992 under the United Kingdom's Tory-led government of John Major (Williams, 2005). PFI is one type of Public-Private Partnerships (PPP) where project financing rests mainly with the private sector (Akintoye et al., 2003). The rationale of PFI is to combine the resources of the public and private sectors for the purpose of providing more efficient public services. In some cases, the capital invested in a project is financed, constructed and leased back to the private sector over a pre-determined period of between 25 and 30 years. This is inline with a number of empirical studies by various researchers (Akintoye et al., 2003; Zhang, 2005; Zhang, 2006; and Pitt \& Collin, 2006) indicating that PFI is a method in which project delivery rests mainly with the private sector, which includes designing, constructing, financing and operating the asset. Dixon et al., (2005) has taken the definition of PFI further by expanding the scope to include financing of long term infrastructure and public services in which, project debt and equity that are used to finance the project are paid back from the cash flow generated by the project. Moreover, Adam (2006); Shen et al., (2006) and Carrilo et al., (2008) reckon PFI as the provision of a public service to meet the needs of public facilities. The basic idea of PFI as noted by Shinohara (1998) is based on the concept that public sector purchases "public services provided by private sector to increase the quality and deliver value for money".

PFI in Malaysia was officially implemented by the Malaysian Government through the Ninth Malaysia- Plan (2006-2010) under the National Privatization Plan (EPU, 2006). It is among the effort by the Malaysian Government to encourage private participation in the local development projects and to reduce government's expenditure in providing public infrastructure and services. PFI transfers to the private sector the responsibility to finance and manage a package of capital investment and services for a Mega project including construction, management, maintenance, refurbishment and replacement of public sector assets. The private sector will create the asset and deliver a service on behalf of the public sector client. In return, the private sector will receive payment commensurate with the levels, quality and timeliness of the service provision throughout the concession period.

Many countries around the world have successfully implemented PFI projects and have benefited from the results. Serco (2007) reckons that the United Kingdom, Japan, Italy, France, Germany, Australia and USA are the world leaders in PFI. In effect, the UK government has been a pioneer of this procurement through concession contracts ranging from 10 to 40 years, embracing services, IT, facilities management, transport, defense, health and education (Smyth \& Edkins, 2007). The trend is also similar to Malaysia. The government of Malaysia is now emphasizing on PFI because PFI is claimed to offer value for money (VFM) than traditional procurement over the life of a project. Indeed, value for money is the main justification for choosing public or private finance for delivering public services (Shoul, 2005; Grimsey \& Lewis, 2005; and Pitt et al., 2006).

Despite PFI being perceived by most governments as the most cost effective means of procuring public infrastructure projects, a debate about the nature and method of achievement of VFM in PFI project is still disparaging (ACCA Survey, 2002). The probable reason for this predicament is due to the difficulty of measuring project outcomes because of the complexities in PFI projects (Broadbent et al., 2003; Heald, 2003; Shoul, 2005; and Khadaroo, 2007). A studies conducted by Shoul (2005) and Leigland \& Shugart (2006) claimed that the complexities of most PFI projects lead to the difficulties to measure VFM for the outcomes. To a certain extent only, one percent of the respondents strongly agreed that PFI generally provides value for money as reported by the ACCA Survey. Therefore, this paper attempts to investigate the notion of value for money (VFM) for PFI projects by different countries such as the UK, Australia and Japan.

The core test of VFM for PFI project is determined through a comparative analysis of the benefits, risks and costs by using both quantitative and qualitative analysis (Grimsey \& Lewis, 2005). According to them, there are four main alternative approaches to provide the core test of VFM. These could be done by using full cost benefit analysis, PSC-PPP comparison, UK style PSC -PPP, and competitive bidding. Among others, the UK style PSC- PPP comparison has been adopted by many countries such as Australia, Hong Kong, Japan, and Canada. Nevertheless, the method has come under growing criticism, in terms of whether PSC calculation is the most appropriate way to evaluate VFM due to the ambiguity and complexity problems.

Hence, this study investigates two fundamental issues; the notion of value for money (VFM) for PFI projects undertaken in different countries such as UK, Australia and Japan, and to examine PSC as a tool in VFM assessments. The research findings will then form the basis for a proposed a model that targets PFI projects in Malaysia.

\section{PFI in Malaysia}

Since 1983, the Malaysian Government has advocated many new forms of PFI modalities such as Built, Operate and Transfer (BOT), Built and Operate (BO), Built Lease Transfer (BLT) for new projects and outright sale, lease, management buy-out and corporatisation for existing projects (Abdul Rashid, 2007). It was officially implemented in 2006 by the Malaysian Government. The main aim was to encourage private participation in the local construction 
development and to reduce government's expenditure in providing public infrastructure and services. The Government sectors that are responsible for establishing the PFI Central Unit include the Ministry of Finance (MoF), Economic Planning Unit (EPU), and National Implementation Directorate (NID). In order to facilitate the implementation of PFIs, the Ministry of Finance Malaysia has acquired a substantial amount of funds to facilitate the first wave of PFI implementation in Malaysia (Jayaselan \& Tan, 2006). The Employee Provident Fund (EPF) Department has agreed to invest RM 20 billion in terms of loan to facilitate PFI projects under the Ninth Malaysia-Plan.

The structure of PFI in Malaysia starts by establishing PFI project agreement which is entered into between the Public sector (represented by various government ministries) and the Special Purpose Vehicle (SPV) Company (private consortium). The PFI Sdn Bhd, a specific government body is set up to administer the Malaysian PFI procurement process. PFI Sdn Bhd borrows money from EPF to finance selected projects under the Ninth Malaysia-Plan. The commitment of PFI Sdn Bhd is to design, construct, operate, manage and maintain the facility throughout the concession periods (Tan et al., 2006). Therefore, the risk associated with the project includes the risk of construction, management, and maintenance of the assets. In return, the Government is contracted to pay for the services based on performance and standard provided. Future tariff revisions are also subjected to a Reward-and-Penalty system (Edge, 2006; Express., 2006; and Kok, 2006).

The evaluation of a project proposal is done through a bidding process and all proposals will be evaluated on the basis of "Value for Money" (VFM) which evaluates its costs and benefits. The bidding proposal is compared against the Public Sector Comparator (PSC) of each project, which acts as a checker to the items and costs stipulated in the tender document. The capital expenditure and the maintenance costs of the project must be less than the PSC benchmark before a PFI project could be awarded to a private partner.

Based on literature reviews by Edge (2006); Hardy (2006); Jayaseelan \& Tan (2006); Netto (2006); EPU (2006); and Zolkepli (2007), the nature of PFI in Malaysia can be divided into two forms. These are government and private sector initiated. The Government sector initiated PFIs is further sub-divided into two categories; PFI projects which falls within the RM 20 billion scope (funded by EPF) and PFI projects which fall outside the RM 20 billion scope. In addition, Jayaseelan \& Tan (2006) point out that the Malaysian PFI deviates from the basic definitions of international PFI framework. The arrangement is different with limited real risk transfer to the private sector since both counter parties to the contract are government entities and also on project financing scheme. The Malaysian version of PFI is financed by the Employee Provident Fund (EPF) loans. Edge (2006) also notes that although financing is provided by the EPF, in return EPF will receive 5 to 6 per cents of the total profits gained out of it. Nevertheless, there is a view that the government could still bear the risk to a certain extent, in particular if any of the PFI project becomes unsuccessful. Although the PFI may have been tested for more than a decade in developing countries such as the UK, Australia, US and others, the appreciation of it is relatively new in Malaysia. The commitment and willingness of the government to bear a substantial portion of the risk (through EPF) even in PFI development projects reflects the high social obligation of government in these projects.

The concept of Malaysia's PFI compose of six major characteristics which includes; (1) partnership of public and private sector; (2) government buys services, not asset; (3) service delivery against specified outputs based on agreed performance standards; (4) whole life costing of a project; (5) detailed and transparent procurement process with competitive tenders which demonstrate value for money rather than lower costs and (6) integration of design, construction finance, and operation. The ultimate purpose is to improve on the inadequacy of the previous privatization program to obtain a better VFM of PFI through a more stringent control over projects.

\section{Value for Money in PFI Projects}

VFM is defined as the 'optimum combination of whole-life costs, benefit, risks, and quality (fitness for purpose) to meet the user requirement and getting the best possible outcome at the lowest possible price' (HM Treasury, 2003; Grimsey, 2005; English, 2006; and Hong Kong Guide to PPP, 2006). It is usually associated with three Es, Economy, Efficiency and Effectiveness (English \& Guthrie, 2003; Grimsey \& Lewis, 2005; and Shoul, 2005). VFM is assumed to be measured using the concept of net present costs, a variant of the net present value technique, involving of 3 step assessment: based on estimate of future cost, risk transfer in delivering whole life economy and the level of the analysis is narrow and focuses on VFM within the agency concerned.

PFI seeks to share risk between the public sector and the private sector in a fair manner. Nevertheless, in PFI there is little actual detailed guidance that has been presented on what VFM is and how it should be achieved (HM Treasury, 2006). Furthermore, the lack of transparency in PFI process contributes difficulty to determine the actual VFM for PFI projects. Therefore, in seeking VFM for PFI projects, three initial strategies should be deployed by most governments. These are: effective evaluation mechanism where there is a clarity of fundamental principle in bidding appraisal; viability of PFI contractor means the capability to fully bear and deliver the required outcomes; and the commitment to VFM means providing a framework VFM assessment. It is important that VFM assessment should take place at the earliest practical stage of any decision making process. 
The process to confirm VFM within PFI procurement is gradual. VFM is assessed by comparing a cost of PFI bids against a PSC. According to the HM Treasury, (2006) PSC is a hypothetical, estimated, risk adjusted, cost of the government itself delivering the project output. It is expressed in terms of the net present cost of providing the output under a public procurement using a discounted cash flow analysis that adjusts the future value of the expected cash flow to a common reference date. It is advisable to construct an initial PSC as early as possible. Theoretically, the project considers VFM if the net present value for PFI bids is lower than the PSC. The baseline cost of the PSC is usually based on historical costs for services that have traditionally been offered by the public sector and adjusted based on project future demand, demographical changes and political consideration. Long term forecasting requires assumptions to be made about the future. Once the NPVs of both PSC and SPV have been prepared and adjusted to a comparable basis, then a simple comparison of both will be carried out.

\section{Methodology}

This is an initial phase of research and purely based on the literature review. It reviews VFM assessment models applied in the UK, Australia and Japan. It addresses six areas of concern: key critical factors (affordability, risk sharing and competition), VFM assessment approach, VFM appraisal, VFM drivers, benefits and barriers that influence to the effectiveness of VFM. The aim is to investigate the notion of VFM for PFI projects by these countries and to discover whether PSC protocol is the most appropriate way to evaluate VFM. Comprehensive empirical research in the form of triangulation approach (questionnaires and case studies) is planned for the findings and conclusion.

\section{Synthesis of VFM Model Assessments}

Table 1 shows the VFM models assessment for PFI projects adopted in the UK, Australia, and Japan. The purpose of adopting these model for the fact that PFI have been in UK, Australia and Japan since 1990s and there are good track record of performances that could be learned, in particular from the VFM point of view. Indeed, the UK is the pioneer of PFI and the inventor in the form of the VFM assessment approach. These models are discussed in turn:

\subsection{The UK's VFM Assessment Model}

The UK VFM assessment model of PFI project by Grimsey \& Lewis (2005); and Pit et al., (2006) outlines a process which starts by looking into key assessment criteria of VFM assessment. These are affordability, risk sharing and competition. Affordability means the appropriately allocation of resources, cost distribution and within the budget, risk sharing is referred to the optimum allocation of risk between private and public sectors and competition means contestability in the market (i.e. in the bidding process and once the contract is concluded and in operation).

The UK model has adopted PSC as a tool when assessing VFM. In making a robust assessment of PFI project, VFM appraisal takes into consideration the financial element (NPV) and qualitative factors (merit base). When the total NPV of private sector supply is less than the NPV of the base cost of the service, adjusted for the cost of risk to be retained by the government (Grimsey \& Levis, 2005). The VFM testing of the PFI option and the PSC should employ economic appraisal principles which include: identification of costs and benefit, calculation of net present value, analysis of uncertainties, weighting of others factors and presentation of result. The results of VFM is demonstrated when the project shows a reduction in cost, innovation in quality and appropriate level of project risk. However, there are some barriers identified in implementation of PSC such as: VFM is too subjective, simplistic and the presence of unquantifiable and risky elements.

In addition, Pit et al., (2006) reckoned several VFM drivers in the UK model such as risk allocation, output specification, competition and private sectors management expertise, nature of contracts (scope, bid cost etc.) and performance measurement. They suggested that, in order to achieve effective VFM drivers; the procurement needs to be well planned, managed, executed and have a transparent process. The assessment of VFM concept in this model can be regarded as complex. It involves the preparation of a hypothetical set of costs of a project, evaluation of risks and financial benefits. To assess VFM therefore, it requires an ability to define, estimate its related outcome and to compare it to alternative approaches. Thus, the project will achieve VFM in terms of comprehensive costing, quality, performance and risk allocation. Nevertheless, the absence of capital funds in PSC calculation is a weakness of the model.

\subsection{The Australian VFM Assessment Model}

The Australia VFM Assessment Model is quite similar to the UK model which also takes into consideration the key assessment criteria, VFM appraisal, PSC, drivers and barriers. However, the dissimilarities are two folds: firstly, VFM is achieved through innovative capabilities, skills to deliver performance improvements, and efficient savings. Secondly, the introduction of the public sector comparator (PSC) and the public interest test (PIT). The primary purpose of PSC is to provide quantitative benchmark against which to judge VFM of bids. The PSC is based on most viable project as a reference. The use of PIT on the other hand, is to ensure that a broader assessment of the public interest to be taken into account before they are offered as Private Finance Project (PFP). Essentially a checklist is needed by PIT and the components of the list include project effectiveness, impact to stakeholders, public access and equality, consumer rights, 
security, privacy and other associated non-economic costs and benefits (English \& Guthrie, 2003). Hence, the two models of VFM assessment of PFI projects the (UK and Australia) seems to be similar in which, both of them emphasizes on raw base cost, transferable risk, retained risk and competitive neutrality.

\subsection{The Japanese VFM Assessment Model}

Following the perceived success of PFI efforts in the UK, the 'PFI Law of Japan' was enacted in 1999. Since then, more than 200 PFI projects have been launched involving various sectors, i.e., public facilities, official facilities and public utilities (Japan PFI Association, 2007). The Japanese PFI utilizes the concept of the UK PFI and modified with Japanese styled subsidies. Construction and application of PSC is an integral component in VFM assessment. VFM is demonstrated by comparing private sector bids with a detailed PSC. The calculation and confirmation of VFM is required from project planning stage. The business period of PFI projects usually lasts for 25-30 years and hence, the NPV method is used for the assessment of VFM. The total amount of a PFI project (including running costs) is converted into NPV to assess the value for PFI project. The assessment for VFM considers for quantitative and qualitative factors, which are identical to the UK and Australia practices. There are some forms of government support specifies as a key drivers under VFM Japanese model including interest free loan from government finance institution and tax measures. The Japanese model of VFM assessment supports the UK approach except in some issues such as long term delivery (i.e., concessionaire) which are not described and discussed in detailed.

\subsection{VFM in Malaysia PFI project}

In the context of Malaysia, three main drivers have been recognized in PFI procurement projects by the Malaysian government. These are: value for money (VFM), efficiency and mobilizing private sector funds. PSC approach is used to measure VFM for PFI projects. The tender bids will be benchmark against the PSCs which remain confidential. It is likely that the Public Works Department will play a key role in drawing up the PSCs for most of the standard construction projects. The formation of PSC is fundamental to the successful of PFI project and appears to be used as a test to achieved VFM.

For genuine efficiency and value for money, it is essential to ensure that contracts are awarded on the basis of capability and ability of PFI contractor. Under PFI, a venture is planned, designed, built, financed and operated by the private sector in return for a steady stream of payments by the government over a set period of time. Typically, the involvement of government is critical in particular, at project planning stage. A set of performance standard is incorporated, while modes of payment are also stipulated. Nevertheless, the establishment of PSC guideline with regards to VFM for PFI contracts is yet to be established (Jayaseelan, 2007). This is paramount for the fact that PSC is subjected to limitations, while VFM is a problematic concept which is hard to operationalise in PFI contracts. In addition, the PSC is subjective and sensitive to changes in cash flows, discounted rates and risks assumption.

\section{A Proposed Framework of VFM Assessment for PFI Projects in Malaysia}

Figure 1, shows the proposed framework for VFM assessment for PFI projects in Malaysia. This has been developed based on the preliminary literature review and the understanding of VFM assessment model adopted by various countries (UK, Australia and Japan). The framework outlines a process which starts by looking into key assessment criteria of VFM assessment including, i.e., affordability, risk sharing and competition. The main reason for using VFM approach is to ensure that risks are fairly distributed between private and public sectors.

The next stage is the VFM assessment approach. In this approach, factors such as contract type, payment mechanism, procurement process, and concession length are the crucial points of the VFM assessment. As a normal practice, PSC is used as a benchmark against the tender bids. Further, in the VFM appraisal, the procuring should consider the quantitative (financial elements), qualitative elements (i.e., bidder's background, design etc) and cost benefit analysis (social obligation) to be formulated into a robust assessment approach. The inclusion of cost benefit analysis is based on the high commitment of the government on its role as a caretaker of the public at large and the social obligation that are naturally attached to it. Cost benefit analysis is the practice of assessing the desirability of projects from the perspective of economist. It takes a wide view in the sense of examining the effect of the project on society, industries and region. It draws on a range of sub disciplines within economist, such as resources economist and public finance to create a coherent view of the project. In this case a number of factors (known as VFM drivers) are listed: Government support, output specification, competition, contract duration and scope, bidding cost, risk allocation, private management skills, client management skill, performance measurement, and contract flexibility (Anderson, 2000; Pitt \& Collins, 2006; and Nisar, 2007). In some cases, the innovation process and commissioning programme are also important to be considered (Pitt \& Collins, 2006).

The benefits of VFM assessment are considered in the form of a whole life cycle, better risk allocation, faster implementation, and improved public services. Despite the benefits, there are obstructions or barriers that could affect the VFM assessment process. Explicitness in public policies, lack of transparency, difficult of assessing the reputation, uncertainty of future events and measurement outcomes are some form of them. The framework aims to achieve VFM 
in terms of three core components; economic, efficiency and effectiveness of PFI projects. These could be translated in the form of optimal risk transfer, innovative design, efficient of public service and leveraging private sector. Nevertheless, more extensive empirical research works on the proposed framework are needed for the future findings in particular to validate the effectiveness of framework.

\section{Conclusion}

This paper attempts to review, synthesize and developed a framework of VFM assessment for PFI project in Malaysia based on the notions of VFM assessment model from the UK, Australia and Japan. It also attempts to investigate the components of PSC as a tool to evaluate VFM. It appears that all these countries are using PSCs mechanism for assessing VFM in procurement, evaluating and quantifying risk. However, there is no one best way of establishing VFM for the fact that assessment of VFM in PFI contract is usually hindered by the lack of transparency and public accountability in the processes. Therefore, it is imperative for Malaysian Government to establish PSC guideline in the evaluation of VFM and to consider VFM critical key drivers. Due to high social obligation placed on PFI projects in Malaysia, the proposed framework of VFM assessment for PFI in Malaysia also include cost benefit analysis as integral components of the VFM appraisal.

The research presented in this paper is part of an ongoing PhD research at Faculty of Architecture, Planning and Surveying, UiTM to develop a framework value for money (VFM) assessment for Public Private Partnership (PPP) projects: Public Sector Projects. The results of the study could provide an insight into the Malaysian construction project development and will hopefully provide valuable guideline, especially to public or private sectors in Malaysia.

\section{References}

Abdul Rashid, K. (2007). Private Finance Initiative (PFI): Concept and method of procurement for construction projects with specific reference to Malaysia. . International Islamic University Malaysia

ACCA Survey. (2002). Do PFI Schemes provide value for money? The Association of Chartered certified Accountants.

Adam, J., Young, A., \& Zhihong, W. (2006). Public Private Partnership in China: System, constraint and future prospects. International Journal of Public Sector management, 19, (4), pp384-396

Akintoye, A., Hardcastle, C., Beck, M., Chinyio, E., \& Asenova, D. (2003). Achieving best value in private finance initiative project procurement. Construction Management and Economics 21, pp 461-470

Arthur Anderson and Enterprise LSE (2000). Value for money drivers in the Private finance Initiative. Report Commissioned by the Treasury Taskforce.

Broadbent, J., Gill, J., \& Laughlin R. (2003). Evaluating the Private Finance Initiative in the National Health Service in the UK. Accounting, Auditing and Accountability Journal. 16 (3).pp $950-114$

Carrillo, P., Robinson, H., Foale, P., Anumba, C., \& Bouchlaghem, D. (2008). Participants, Barrier and opportunities in PFI: The United Kingdom experience. Journal of management In Engineering, pp138-145

Dixon, T., Pottinger, G., \& Jordon, A. (2005). Lesson from the private finance initiative in the UK :Benefit, problems and critical success factor. Journal of property investment and finance, 23 (5), pp. 412- 423.

Edge, T. (2006). Untested model for Malaysian companies. The Edge Malaysia, p. 75.

English, L. (2006). Public private partnership in Australia: An overview of their nature, purpose, incidence and oversight, UNSW Law journal, 29,pp 250-262.

English, L., \& Guthrie, J. (2003). Driving privately financed projects in Australia: What makes them tick? Accounting, Auditing \& Accountability Journal, 16(3), pp 493-511.

Express, D. (2006). Tenders for RM15b projects out in three months. Daily Express. Retrieved 11 February, 2006, from the World Wide Web: http://www.dailyexpress.com.my/print.cfm?NewslD=43287

Fernando, D., Tsutsumi, M., Ishida, H., \& Okamota, N. (2005). Private finance for road projects in developing countries: Improving transparency through VFM risk assessment. Journal of the Eastern Asia Society for transportation studies, 6 , pp 3899-3914

Froud, J. (2003). The private finance Initiative: Risk, uncertainty and the state. Accounting, organization and society (28) pp 567-589

Grimsey, D., \& Lewis, M.K. (2005). Are Public Private Partnership Value for money? Evaluating alternative approaches and comparing academic and practitioner view. Accounting forum (29) pp $345-378$

Hardy, A. (2006). TSR-Tabung Haji in RM3b medical city project The Edge Daily. [Online] Available: http://www.uitm.edu.my/news_events/06/060718_TSR_TabungHaji_3b_MedicalCity.html

Heald D. (2003). Value for money test and accounting treatment in PFI schemes. Accounting, Auditing and Accountability Journal . 16 (3). pp 342- 371

HM Treasury. (2006). Value for money assessment guidance @ Crown copyright 
HM-Treasury. (2003). PFI: meeting the investment challenge. London. : (C) Crown copyright 2003

Hong Kong PPP Guide. (2006). Making the business case. An introductory guide to Hong Kong Public Private partnership.

Japan PFI Association. (2007). Japan's Private Finance Initiative on the move. Retrieve October 2008.

Jayaseelan, R. (2007). Cover story : PFI guidelines out soon. The Egde Malaysia. The Edge Communication Sdn Bhd. Jayaseelan, R., \& Tan, M. (2006). PFI-cure for all ills? The Egde Malaysia, pp. 72-74. The Edge Communication Sdn Bhd.

Kajita, S. ( 2007). Application of PPP/PFI to social overhead capital development. Journal of Public policy \& management (2).

Khadaroo, I. (2007). The actual evaluation of school PFI bids for value for money in the UK public sector (in press): Critical Perspectives on Accounting.

Kok, M.K. (2007). Construction sector 2007 outlook. Amresearch Sdn Bhd.

Leigland, J \& Shugart, C. ( 2006). Is the public sector comparator right for developing countries? Gridlines. Public private infrastructure advisory facility.

Mori, N. ( 2006). Challenges and prospects for the Japanese PFI, Research department, KRI International Corp.

Netto, A. (2006). Malaysia's newfangled privatization fudge. EPU. (2006).

Ninth Malaysian Plan. (2006). Putrajaya: Prime Minister's Department. Retrieved August 17, 2006. [Online] Available: www.hm.treasury.gov.my

Nisar, T.M. (2007). Value for money drivers in public private partnership schemes. International Journal of Public Sector Management, 20 (2), pp 147-156.

Partnership Victoria. (2006). Department of Treasury and Finance, Victoria.

Pitt, N \& Collins, N. (2006). The private finance initiative and value for money. Journal of property investment and finance, 24 (4), pp 363-373

Serco. (2007). PPP/PFI. The Serco Institute. Retrieved 23 January, 2007.

Shen, Y.L., Platten, A \& Deng X.P. (2006).Role of public private partnership to manage risks in public sectors projects in Hong Kong. International journal of Project management, 24. pp 587-594.

Shinohara, F. (1998). Perspective on Private Finance Initiative in Japan : The impact on administrative reform, social infrastructure and public services, Urban Development department, NLI Research Institute, (117), pp 27-38.

Shoul, J. (2005). A critical financial analysis of the private Initiative: Selecting a financing method or allocating economic wealth, Critical Perspective on Accounting, 16, pp 441-471.

Smyth, H., \& Edkins, A. (2007). Relationship management in the management of PFI/PPP projects in the UK. International Journal of Project Management, 25, 232-240.

William.T. (2005). Moving to Public Private partnership

Zhang, X. (2005). Paving the way for public private partnership in infrastructure development. Journal of construction Engineering and Management 131, (1) pp 71-80.

Zhang, X. (2006). Factor analysis of Public Clients Best value Objective in Public Privately partnered infrastructure project. Journal of Construction Engineering and Management . pp 956-965

Zolkepli, F. (2007). Aman signs MoU on resort. The Star Online. 
Table 1. VFM assessment for UK, Australia and Japan

\begin{tabular}{|c|c|c|c|}
\hline Variables & $\begin{array}{l}\text { UK VFM Model } \\
\text { (Grimsey and Lewis, } 2005 \\
\text { and Pit et al. } 2006\end{array}$ & $\begin{array}{l}\text { Australia VFM model } \\
\text { (Partnership Victoria, 2006) }\end{array}$ & $\begin{array}{l}\text { Japanese VFM model } \\
\text { (Mori, N, } 2006 \text { and Kajita, } \\
\text { 2007) }\end{array}$ \\
\hline $\begin{array}{l}\text { Key assessment } \\
\text { criteria }\end{array}$ & $\begin{array}{ll}\text { - } & \text { Affordability } \\
\text { - } & \text { Risk Sharing } \\
\text { - } & \text { Competition } \\
\text { - } & \text { Public Sector } \\
& \text { Comparator (PSC) }\end{array}$ & $\begin{array}{ll}\text { - } & \text { Affordability } \\
\text { - } & \text { Risk Sharing } \\
\text { - } & \text { Competition } \\
\text { - } & \text { Public Sector Comparator } \\
& \text { (PSC) } \\
\text { - } & \text { Public interest test (PIT) }\end{array}$ & $\begin{array}{ll}\text { - } & \text { Affordability } \\
\text { - } & \text { Risk Sharing } \\
\text { - } & \text { Competition } \\
\text { - } & \text { Public Sector } \\
& \text { Comparator (PSC) }\end{array}$ \\
\hline VFM Appraisal & $\begin{array}{l}\text { - Financial (net present } \\
\text { value) } \\
\text { - } \text { Qualitative (merit base) }\end{array}$ & $\begin{array}{l}\text { - Financial (net present } \\
\text { value) } \\
\text { - } \text { Qualitative (merit base) }\end{array}$ & $\begin{array}{l}\text { - Financial (net present } \\
\text { value) } \\
\text { - } \quad \text { Qualitative (merit base) }\end{array}$ \\
\hline Barriers & $\begin{array}{ll}\text { - } & \text { Subjective } \\
\text { - } & \text { Simplistic } \\
\text { - } & \text { Unquantifiable } \\
\text { - } & \text { Risk } \\
\text { - } & \text { Incomplete }\end{array}$ & $\begin{array}{l}\text { - } \text { Inaccuracy } \\
\text { - Omitted risks } \\
\text { - Manipulation } \\
\text { - High cost } \\
\text { - No consensus on discount } \\
\text { rate } \\
\text { - No public sector } \\
\text { alternative }\end{array}$ & $\begin{array}{l}\text { - Complexity of } \\
\text { procedures } \\
\text { - Bureaucracy } \\
\text { - Disclosed of information } \\
\text { - Lack of a transparency }\end{array}$ \\
\hline VFM Drivers & $\begin{array}{ll}\text { - } & \text { Risk allocation } \\
\text { - } & \text { Output specification } \\
\text { - } & \text { Competition } \\
\text { - } & \text { Contract duration and } \\
& \text { scope } \\
\text { - } & \text { Bid cost } \\
\text { - } & \text { Innovation } \\
\text { - } & \text { Borrowing cost } \\
\text { - } & \text { Private and client } \\
\text { - } & \text { Performanement skills } \\
& \text { measurement } \\
\text { - } \text { Contract flexibility }\end{array}$ & $\begin{array}{l}\text { - Definable and measurable } \\
\text { - } \text { - Whorvice output. } \\
\text { - Integration of design, } \\
\text { operation and maintenance } \\
\text { - Opportunity for innovation } \\
\text { - Risk transfer } \\
\text { - Greater asset utilization } \\
\text { - Market capability }\end{array}$ & $\begin{array}{l}\text { - } \text { Government support } \\
\text { - Deregulation and } \\
\text { opening market to } \\
\text { private sector } \\
\text { - Private sector capability } \\
\text { and expertise } \\
\text { - Proper contract } \\
\text { conditions } \\
\text { - Private willing accept } \\
\text { risk } \\
\text { - Capacity of financial } \\
\text { markets }\end{array}$ \\
\hline $\begin{array}{l}\text { Comprehensive } \\
\text { VFM concept }\end{array}$ & $\begin{array}{l}\text { - } \text { Economy } \\
\text { - } \text { Efficient } \\
\text { - } \quad \text { Effectiveness } \\
\text { Achieving : } \\
\text { - } \text { Optimal risk transfer } \\
\text { - } \quad \text { Efficient of public } \\
\text { services } \\
\text { - Innovative design } \\
\text { - } \quad \text { Leveraging private } \\
\text { sector }\end{array}$ & $\begin{array}{l}\text { - } \text { Economy } \\
\text { - } \text { Efficient } \\
\text { - } \text { Effectiveness } \\
\text { Achieving : } \\
\text { - } \text { Optimal risk transfer } \\
\text { - } \quad \text { Efficient of public services } \\
\text { - Innovative design } \\
\text { - } \quad \text { Leveraging private sector }\end{array}$ & $\begin{array}{l}\text { - } \text { Economy } \\
\text { - } \text { Efficient } \\
\text { - } \quad \text { Effectiveness } \\
\text { Achieving : } \\
\text { - } \text { Optimal risk transfer } \\
\text { - } \quad \text { Efficient of public } \\
\text { services } \\
\text { - Innovative design } \\
\text { - } \quad \text { Leveraging private } \\
\text { sector }\end{array}$ \\
\hline
\end{tabular}

Source: Grimsey and Lewis (2005)., Pit et al. ( 2006)., Partnership Victoria (2006)., Mori, (2006) and Kajita, ( 2007) 


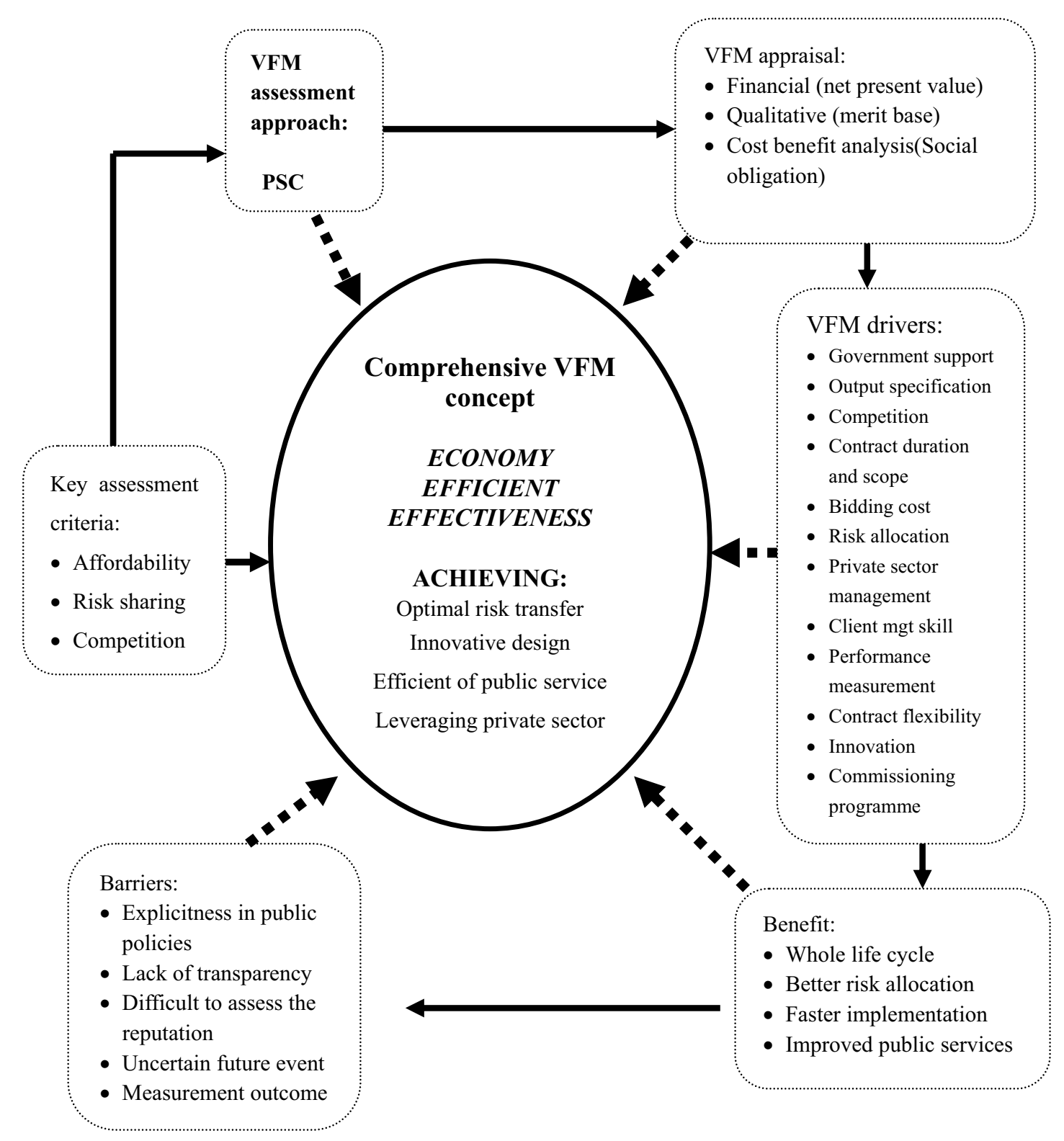

Figure 1. Propose a framework of VFM assessment for PFI projects in Malaysia 